\title{
Study of the Purification Performance of Sand Filter Drained in a Complementary Treatment of Urban Wastewater under Soil and Climatic Conditions of the Southern Tunisia
}

\author{
S. Eturki ${ }^{1}$, H. Makni ${ }^{2}$, R. boukchina ${ }^{3}$, H. Ben Dhia ${ }^{2}$ \\ ${ }^{1}$ Wastewater Treatment Laboratory, Water Researches and Technologies Centre, Soliman, Tunisia \\ ${ }^{2}$ Water, Energy and Environment Laboratory, National School of the Engineers of Sfax, Sfax, Tunisia \\ ${ }^{3}$ Water and Soil Laboratory, Institute of Arid Lands Nahhal, Gabès, Tunisia \\ E-mail: turkisaifeddine@yahoo.fr \\ Received May 7, 2011; revised June 8, 2011; accepted July 4, 2011
}

\begin{abstract}
Infiltration percolation is a rustic and extensive purifying technique which is capable of completely oxidizing and decontaminating wastewater. The object of the present study is to validate on a real scale the findings gotten in pilot laboratory. It is notably to confirming the purification performances and decontamination of secondary effluent by sand filter drained under an intense wild plant. For this, a basin of $100 \mathrm{~m}^{2}$ of infiltration surface equipped with two wells of sampling in the center and in the periphery, has been constructed in irrigated perimeter of Dissa in Gabes (south east of Tunisia). Our results show that essential of the COD is eliminated in first 50 centimeters in sand filter and the presence of wild plant on the surface of infiltration damaged quality of filtered water. The follow-up of the organic nitrogen and ammonium show the good performances of process in elimination of nitrogenous pollution. The rate of exhaustion is about $100 \%$ and this since first 50 centimeters of filtration. The sand filter retains the different shapes of the phosphor by adsorption and precipitation in the superficial horizon. The elimination of the bacterial pollution is high, it varying from 0.1 to 2.5 Ulog. The bacterial purification remained low after $50 \mathrm{~cm}$ filtration. Indeed, with $50 \mathrm{~cm}$ depth, the quality of the filtrate is slightly better than the influent with still tendency to higher removal in the center than in periphery of the basin.
\end{abstract}

Keywords: Infiltration Percolation, Purification, Depth of the Sand Filter, Covered Plant

\section{Introduction}

It is generally admitted that the tertiary treatment attached sometimes in the conventional stations (chlorinetion, ultraviolet, ozone...) is very costly or have a questionable efficiency. Only the extensive processes seem to be capable to disinfect waters used in appropriate economic conditions [1]. Infiltration percolation is an extensive treatment process aimed at eliminating organic pollution, oxidizing ammonium and removing pathogens [2]. It has been increasingly used for the treatment of primary or secondary wastewater effluents because of its low energy and requirements maintenance [1]. It consists in the intermittent application of sewage on buried sand filters or permeable native soils. The infiltrated water percolates through unsaturated porous medium. The treated water is collected by a drainage system or percolates down to the underlying aquifer [3].

Research and field experiments have shown that intermittent filtration can provide high removal efficiency of bacteria if properly designed and operated [4]. Therefore secondary treated effluents can be used for unrestricted agricultural irrigation [5], irrigation of public parks, lawn sand golf courses [6] and ground water recharge [7].

Research works undertook by Institute of Arid lands in Gabes and National School of Engineers of Sfax achieved on pilots of laboratory permitted to show that infil- 
tration percolation is one of the rare extensive techniques capable to function for a long time in Tunisia sub-Sahara; while satisfying the physico-chemical, bacteriological and parasitological purification objectives [8,9]. These studies permitted to elaborate the first applications under soil and climatic context of the Tunisian south.

The first aim of this work was to determine the performances of the Dissa infiltration percolation basin in the oxidation of organic matter and nitrogen. The second aim was to contribute to better describe the oxidation mechanisms in presence of wild plant to improve the technique. Assessing disinfection performances of the filtering bed in presence and in absence of vegetation was a third objective.

\section{Materials and Methods}

Experiments were investigated in $100 \mathrm{~m}^{2}$ sand filter located at Dissa agriculture area in the north of Gabes City (south-east of Tunisia). The sand filter is a trapezoidal basin with $2 \mathrm{~m}$ in height and filled with $30 \mathrm{~cm}$ of coarse gravel and $1.5 \mathrm{~m}$ of sand. The mean grain size of sand $\left(d_{50}\right)$ is $0.26 \mathrm{~mm}$ and the uniformity coefficient of the particle-size distribution $\left(\mathrm{d}_{60} / \mathrm{d}_{10}\right)$ is 1.93 (Figure 1). A polyethylene pipe was used drilled with $0.5 \mathrm{~cm}$ holes to drain filtered water out. The experimental arrangement is depicted in Figures 2 and 3. We carried out infiltration trials using secondary wastewater effluents produced by Gabes City treatment plant which employs activated

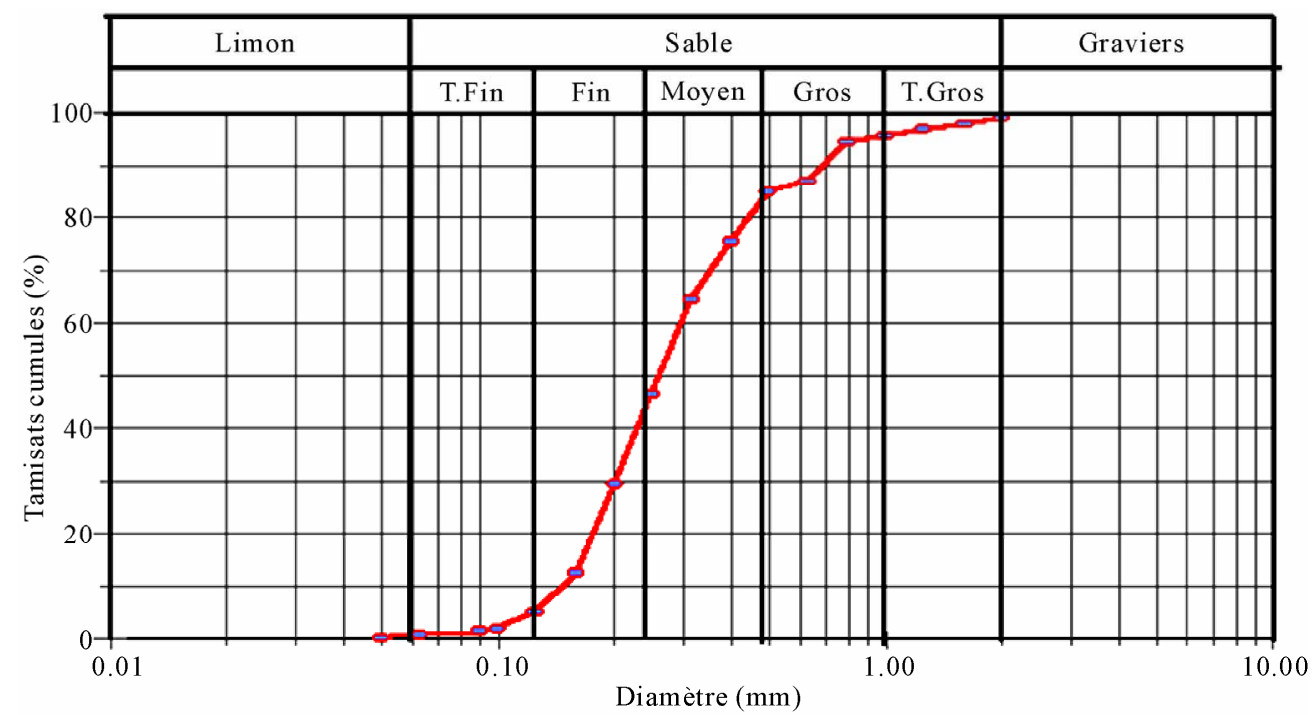

Figure 1. Grain sizes of used sand filter.

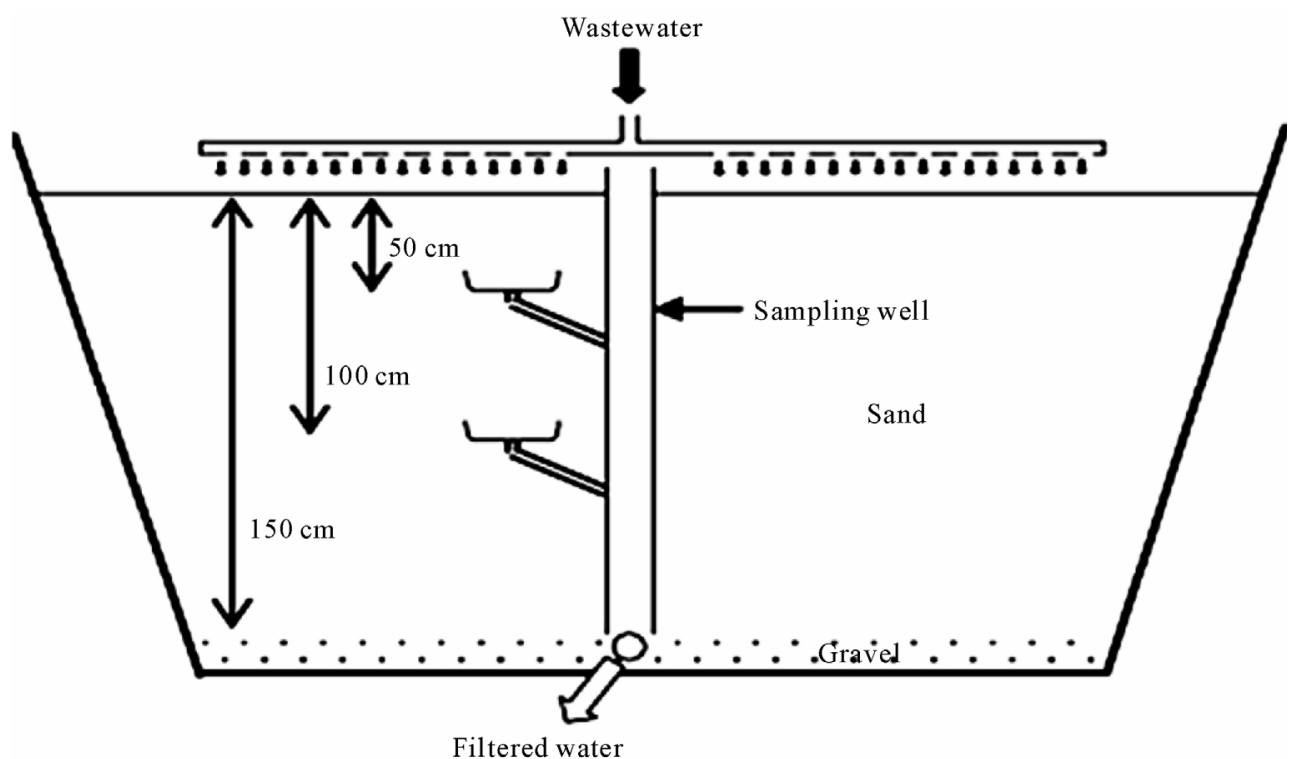

Figure 2. Tentative unit of infiltration: Dissa basin with its system of alimentation. 


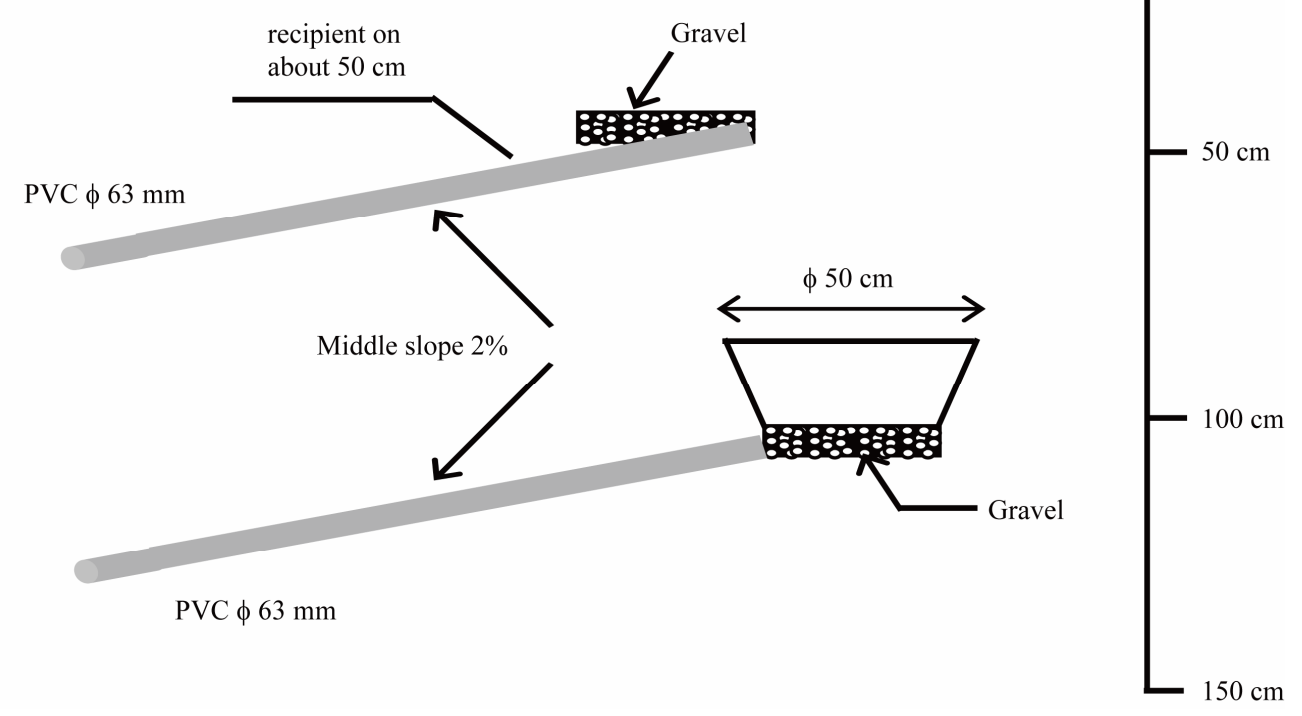

Figure 3. The system of sampling to different depths of the sand filter.

sludge treatment with a capacity of $17,000 \mathrm{~m}^{3} / \mathrm{d}$. In previous work [10], the optimum hydraulic loading rate to improve secondary wastewater quality by intermittent sand filter for a single application was evaluated at 27 $\mathrm{cm} / \mathrm{d}$. In this study the operation mode conditions rotated through a 7-day cycle consisting a 4-day flooding period during which the basin received a volume of $27 \mathrm{~m}^{3} / \mathrm{d}$ of secondary wastewater effluents and a 3-day drying period during which the basin is allowed to dry out thoroughly. Wetting/drying operation serves several purposes, including maintenance of aerobic conditions in the upper soil layers [11]. Performances of the sand filter have been investigated during a period of 8 months. Secondary effluents and filtered water were analysed for chemical oxygen demand (COD), Phosphor $\left(\mathrm{PO}_{4}^{3-}\right)$, Kjeldahl nitrogen (NTK), ammonium (N-NH$)$, nitrates $\left(\mathrm{N}-\mathrm{NO}_{3}\right)$, Pseudomonas aeriginosa $(\mathrm{Pa})$, faecal coliforms (FC) and streptococci (FS), $\mathrm{pH}$ and electric conductivity were measured. In order to evaluate the effects of wild plant on oxidation performances of infiltration percolation, two experimental periods were investigated.

\section{Results and Discussions}

\subsection{Purification Performance Studies in Presence of Vegetation}

During the period of experimentation, the incidental exhaustion of COD is valued to $60 \%$. On the other hand this output was of $80 \%$ in wintry period in absence of vegetation on the surface of basin. However, the oxy- genation of the porous media remained insufficient and the exhaustion of the COD is only $48 \%$ in the center and $58 \%$ in the periphery at $50 \mathrm{~cm}$ depth, the total output of the basin is about $60 \%$. Meftah [12] gets some results meaningfully better when the beach of infiltration was free. Therefore, vegetation affects negatively the oxidization of the carbon pollution. One also notices that the thickness of the filterable massif doesn't play a role in the elimination of the organic matter beyond thickness of $50 \mathrm{~cm}$. The potentialities of the infiltration basin seem to be raised for the elimination of phosphates. The contents in the filtrate are always weak (Figure 4). In treated water the output is from $90 \%$; at $50 \mathrm{~cm}$ depth the elimination also remains very high with an output of $83 \%$ in center and periphery of the basin. The phosphor is therefore very easily eliminated from wastewater since the first 50 centimeters in sand filter despite the presence of vegetation. According to Burkitt et al. [13], these outputs raised of the removal of the phosphor could be explained by two parameters: the sand filter keeps the different shapes of phosphor by adsorption, and by precipitation.

The follow-up of the organic nitrogen and ammonium shows good performances process in the removal of nitrogenous pollution. The outputs reach values near from 100\% (Figure 5). Waters applied on the filter are characterized respectively by middle concentrations in Kjeldahl nitrogen and ammonium equal to $24 \mathrm{mg} / \mathrm{l}$ and $19 \mathrm{mg} / \mathrm{l}$ respectively. In the filtered water, the middle vestigial contents are $0.64 \mathrm{mg} / \mathrm{l}$ and $0.15 \mathrm{mg} / \mathrm{l}$ respecttively. Nitrogen under its oxidized shapes is eliminated at $98 \%$ in the sand filter. At $50 \mathrm{~cm}$ depth, the elimination of the 


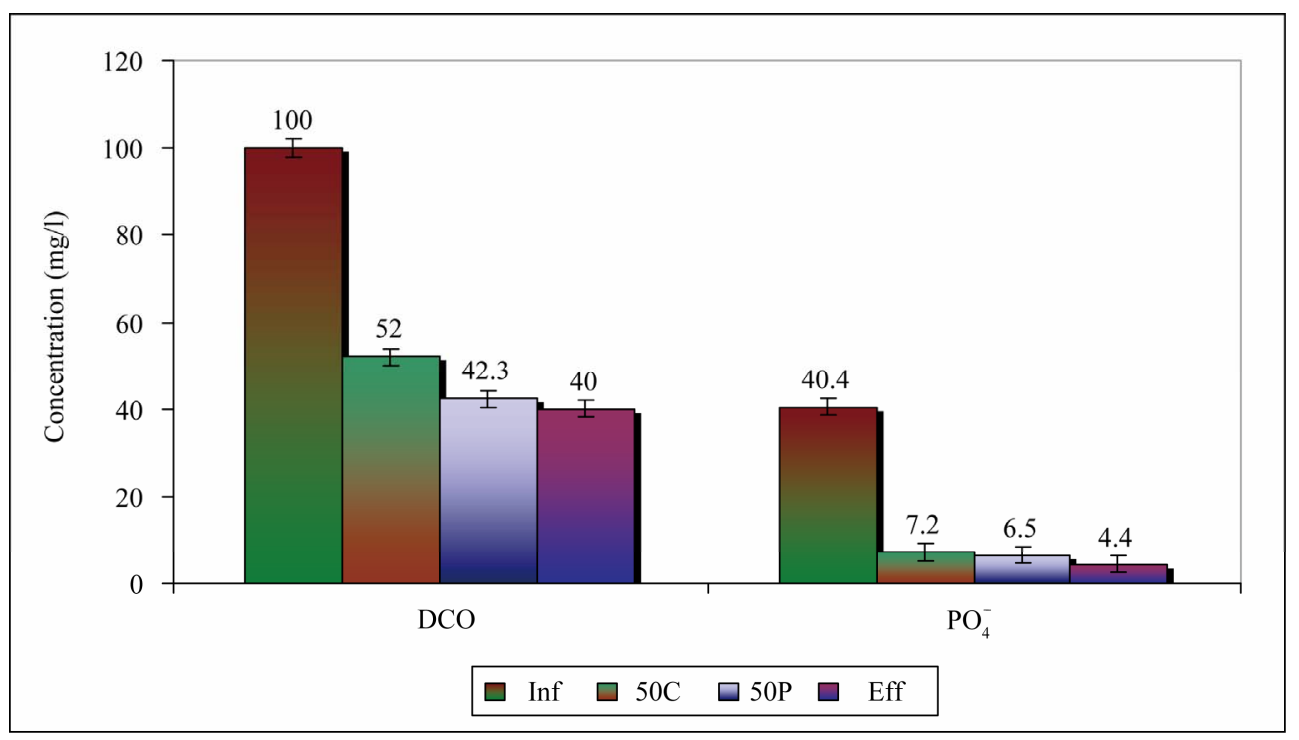

Figure 4. Concentrations of the COD and $\mathrm{PO}_{4}^{3-}$ in influent, in $50 \mathrm{~cm}$ and in the effluent.

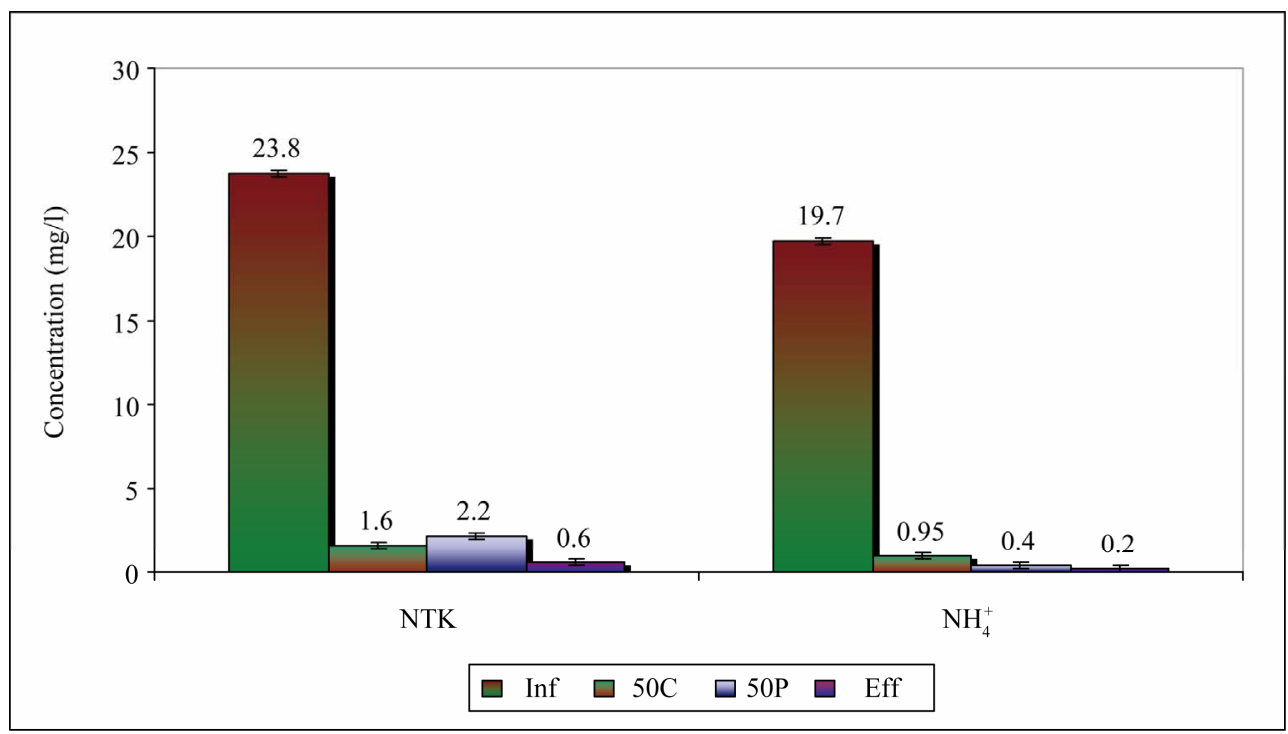

Figure 5. Concentrations of the nitrogenous pollution in influent, in $50 \mathrm{~cm}$ and in the effluent.

total nitrogen is high in the center of the basin than in the periphery; the vestigial contents are of $1.5 \mathrm{mg} / \mathrm{l}$ and $2.3 \mathrm{mg} / \mathrm{l}$ respectively corresponding to outputs of 93 and $90 \%$ respectively. To this same depth the elimination of $\mathrm{N}-\mathrm{NH}_{4}^{+}$is very weak, $0.95 \mathrm{mg} / \mathrm{l}$ in the treated water and the middle contents in the center and in the periphery are $0.45 \mathrm{mg} / \mathrm{l}$. the wild plant on sand filter doesn't affect the removal efficiency of nitrogen. It is in agreement with the works of Brissaud et al. [14] that notes essential of the nitrification happens in the first 50 centimeters of a column of $1.5 \mathrm{~m}$ of the fine sand that treats a hydraulic load of $75 \mathrm{~cm} /$ day of septic sewage.

The elimination of the bacterial pollution is varying from 0.1 to 2.5 Ulog. The bacterial purification remained weak after $50 \mathrm{~cm}$ filtration. Indeed, to $50 \mathrm{~cm}$ depth, the quality of the filtrate is slightly better than influent with still tendency to higher removal in the center than in periphery of the basin (Figure 6). The exhaustion of fecal Coliforms CF in this depth doesn't exceed 0.75 Ulog. To the basis of the sand filter, removal of CF can reach two logarithmic units. The contents of fecal Streptococci are near applied wastewater content. It is necessary to reach $1.5 \mathrm{~m}$ of depth so that the fecal Streptococci exhaustion stabilizes during the whole tentative period and reaches an average of 2 Ulog. Some comparable results are found by bali et al. [9] on the same Basin. Wild plant affects negatively the removal efficiency bacteria especially in the superficial depth because the preferential percolation 


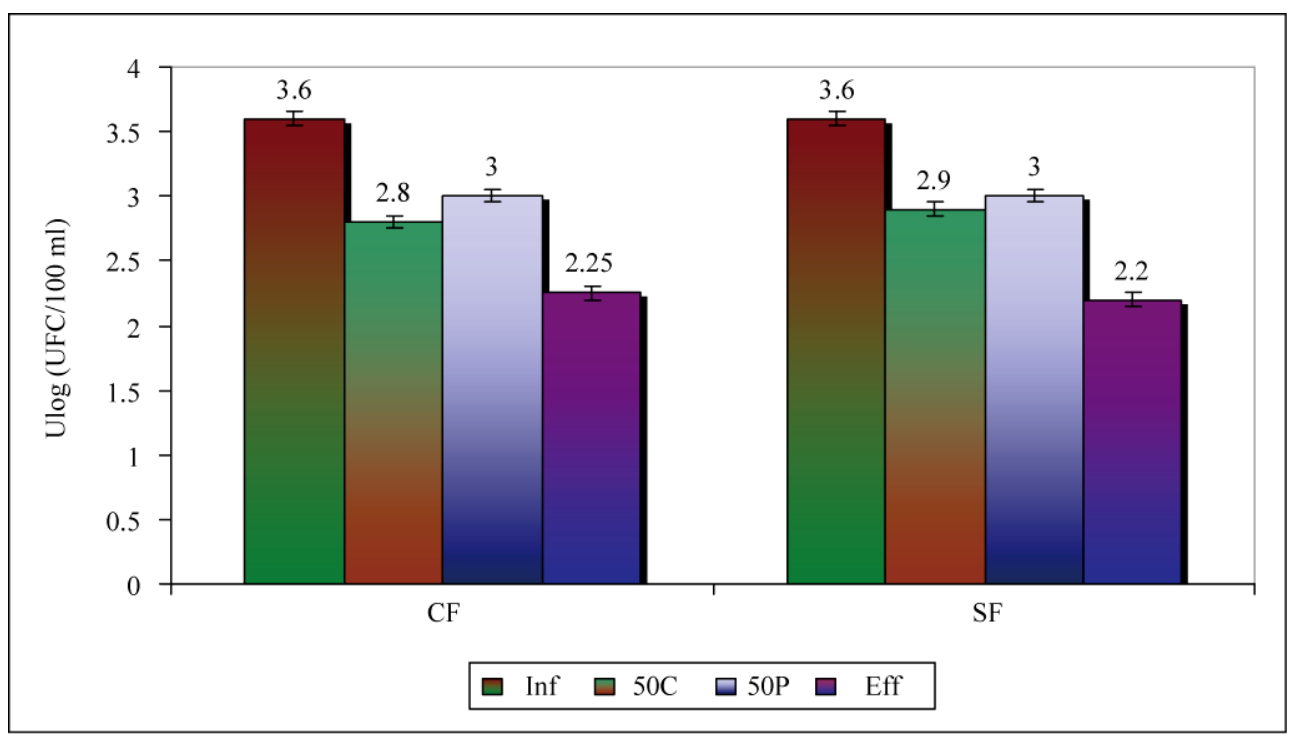

Figure 6. Contents in CF and SF in the wastewater before, to $50 \mathrm{~cm}$, and after treatment by infiltration percolation.

of wastewater with the developed roots of plants.

\subsection{Purification Performance Studies in Different Depths of Sand Filter}

During this second experimentation period, the vegetal cover is completely eliminated from the filter; COD of applied secondary sewage has middle value of $170 \mathrm{mg}$ $\mathrm{O}_{2} / 1$. The removal of the carbon pollution is satisfactory in winter with a global output of $80 \%$ after $1.5 \mathrm{~m}$ filtration. $100 \mathrm{~cm}$ of filtration permit to eliminate $78 \%$ of the COD in center of the basin and $69 \%$ in its periphery, with vestigial contents of the order of $38 \mathrm{mgO}_{2} / \mathrm{l}$ and $53 \mathrm{mg} \mathrm{O}_{2} / 1$ respectively. After $50 \mathrm{~cm}$ of filtration, the elimination of the carbon pollution is only $52 \%$ in center and $45 \%$ in periphery, the vestigial COD being in order to $83 \mathrm{mg} \mathrm{O}_{2} / \mathrm{l}$ and $94 \mathrm{mg} \mathrm{O}_{2} / \mathrm{l}$ respectively.

This test shows that the superficial layers of filter play an essential role in the removal of the COD; therefore about $50 \%$ of the organic load is eliminated already after $50 \mathrm{~cm}$ of filtration depth. It is especially important than the carbon pollution constitutes the responsible factor for the development of biomass. This biomass develops itself therefore less in superficial layers depth. It has important consequences in the management and the durability of the system. A depth of $100 \mathrm{~cm}$ appears sufficient for the elimination of the organic matter. The middle vestigial COD in this depth being the order of $46 \mathrm{mg} \mathrm{O}_{2} / \mathrm{l}$. Bali and al., [9] show also that the devices of infiltration are very effective for the elimination of the organic matter, whose big part makes itself on the superficial layers of the filter.

The middle concentration in orthophosphates observed during this period is about $71 \mathrm{mg} / \mathrm{l}$ in the influent. In effluent it is about $24.5 \mathrm{mg} / \mathrm{l}$ what corresponds to removing of $65 \%$. The elimination of the phosphor is relatively variable for the same depth, it is more higher in the periphery than in center of the basin. The outputs reach $67 \%$ to $50 \mathrm{~cm}$ and $75 \%$ to $100 \mathrm{~cm}$ depth; therefore the global output pass extensively out of the basin and it is about $65 \%$. In the center of basin, these outputs remain lower on the other hand always to the output of treatment system and are from $49 \%$ after $50 \mathrm{~cm}$ filtration and 55\% after $100 \mathrm{~cm}$ depth with middle vestigial contents of $36 \mathrm{mg} / \mathrm{l}$ and $31 \mathrm{mg} / \mathrm{l}$ respectively (Figure 7). According to Meftah [12], the performances of the systems of infiltration percolation in the elimination of the orthophosphates depend on electro-chemical conditions of middle and the mineralogical composition of the sand filter.

The retention of the Kjeldahl nitrogen is highly effecttive since the first week of drying. 96\% of this nitrogen is kept in the sand filter (Figure 8). On the other hand, we didn't note sensitive variations of the vestigial content of the percolate in total nitrogen in different depths. In $50 \mathrm{~cm}$ depth, the elimination of total nitrogen is already raised with an output of $82 \%$ in the center and $78 \%$ in periphery and the contents are 1.8 and $2.2 \mathrm{mg} / \mathrm{l}$ respectively. After $100 \mathrm{~cm}$ filtration, the total nitrogen has been eliminated at the rate of $93 \%$ in the center and $87 \%$ in the periphery respectively with middle vestigial contents of $0.7 \mathrm{mg} / \mathrm{l}$ and $1.4 \mathrm{mg} / \mathrm{l}$. The nitrification in 100 $\mathrm{cm}$ is globally similar to $150 \mathrm{~cm}$. The concentration of the filtrated water in nitrates is about $15 \mathrm{mg} / \mathrm{l}$ whereas it reaches $30 \mathrm{mg} / \mathrm{l}$ in $50 \mathrm{~cm}$ depth. The concentrations raised to $50 \mathrm{~cm}$ depth explain themselves by a washing of the nitrates accumulated in sand filter at the time of previous drainage period, and also it may come from oxidization of ammonium adsorbed during the previous 


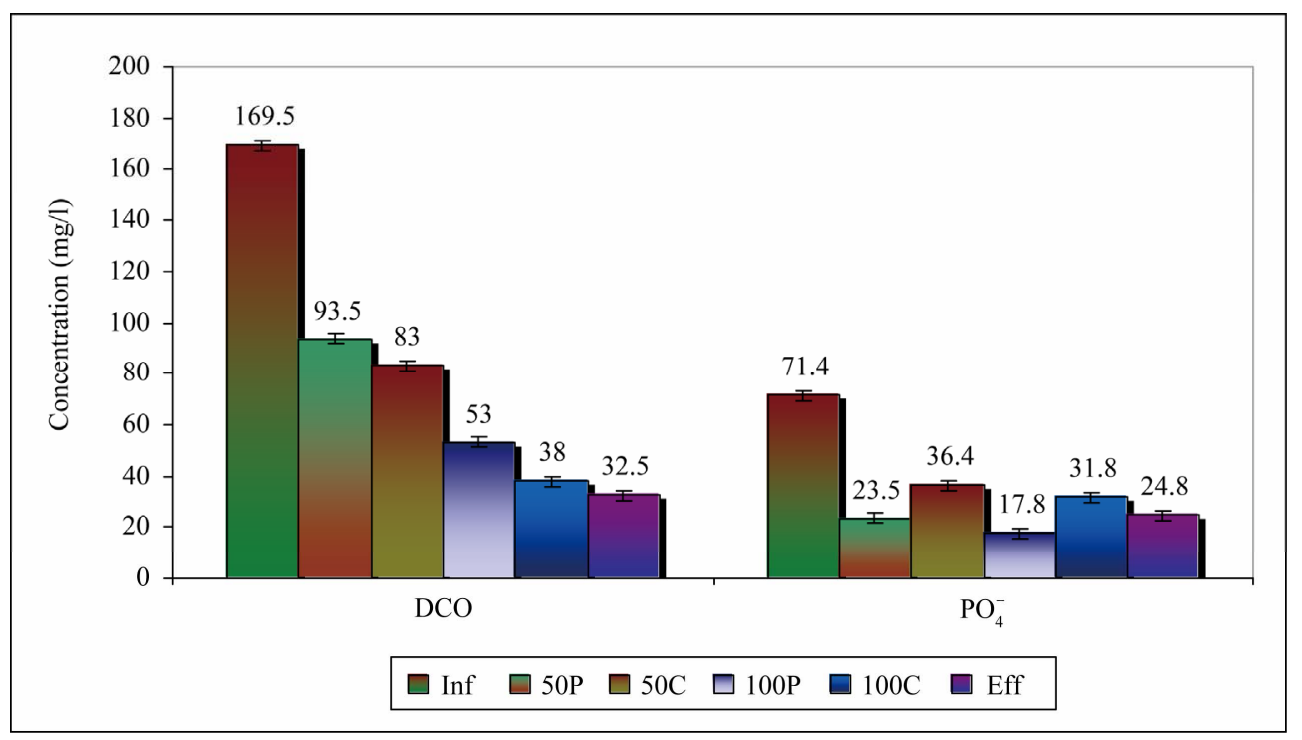

Figure 7. Concentrations of the COD and $\mathrm{PO}_{4}^{3-}$ in the influent, in $50 \mathrm{~cm}$, in $100 \mathrm{~cm}$ and in the effluent.

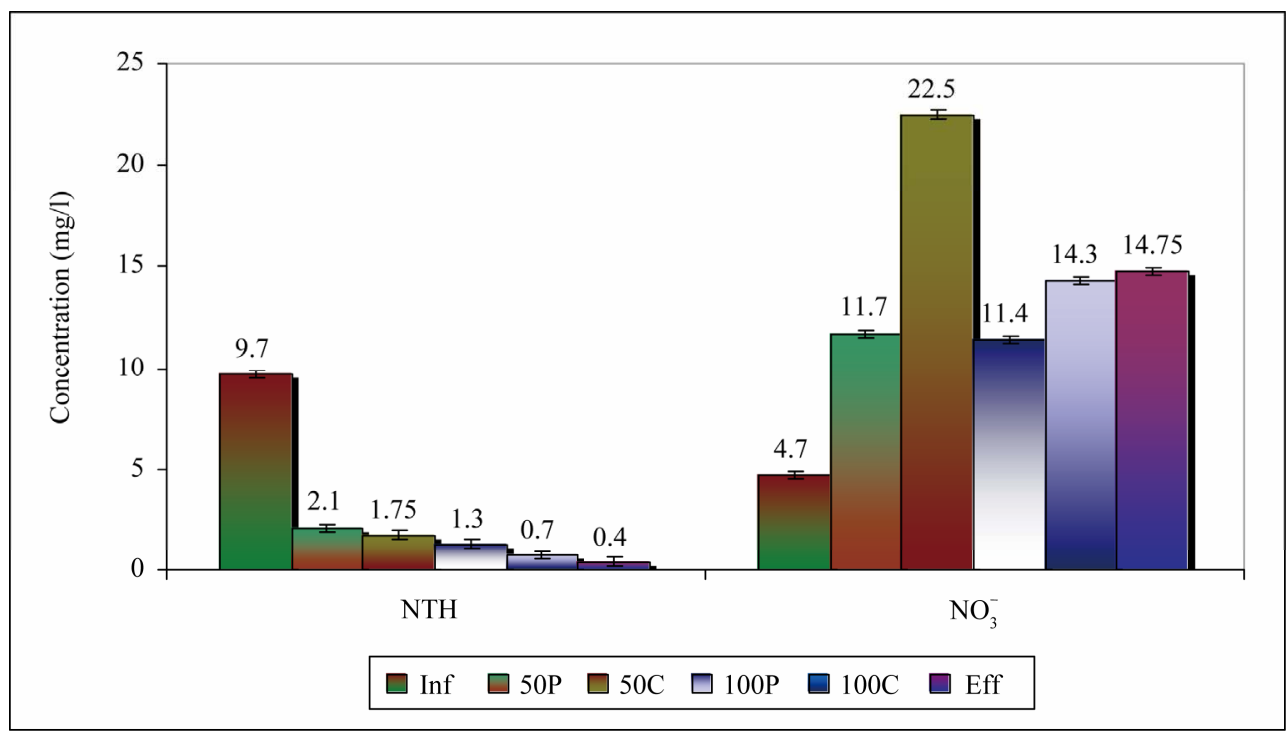

Figure 8. Concentrations of the nitrogenous pollution in influent, in $50 \mathrm{~cm}$, in $100 \mathrm{~cm}$ and in the effluent of the basin.

alimentation. These results confirm the works of [15] that prove a big part of nitrogen is fixed in the first centimeters of sand filter.

The removal of the fecal Coliform and the fecal streptococci is 2.2 Ulog in treated water. The microbial quality of the filtrated water collected to $50 \mathrm{~cm}$ depth in the center and in periphery of the basin is appreciably identical to the influent of wastewaters applied on the filter. The residence times of this wastewater in sand filter are short, in the score of minutes that follow the application of the volume of wastewater; the porous media is saturated by very loaded water in organic matter. These conditions are not indeed favorable to elimination of bacteria. After $100 \mathrm{~cm}$ filtration exhaustion is about $1.4 \mathrm{Ulog}$. Th- erefore the last $50 \mathrm{~cm}$ of sand filter play an essential role in the sanitary quality of purified water. The bacteriological criteria's of no restraining reuse are satisfied extensively. Some comparable results are found by [9] at the time of a survey achieved on a same basin. These authors show that the removal of Coliform is bound in the real residence time in sand filter and the temperature of water. Compared to the other germs of fecal contamination, the exhaustion of the Pseudomonas Aeriginosa (pathogen) is raised in the beginning of the test. Therefore after 15 days of drying, we note a tendency to the stability of the concentration of the Pseudomonas Aeriginosa in treated water in different depths (Figure 9). We note, as for the other germs, an increase of removal with the 


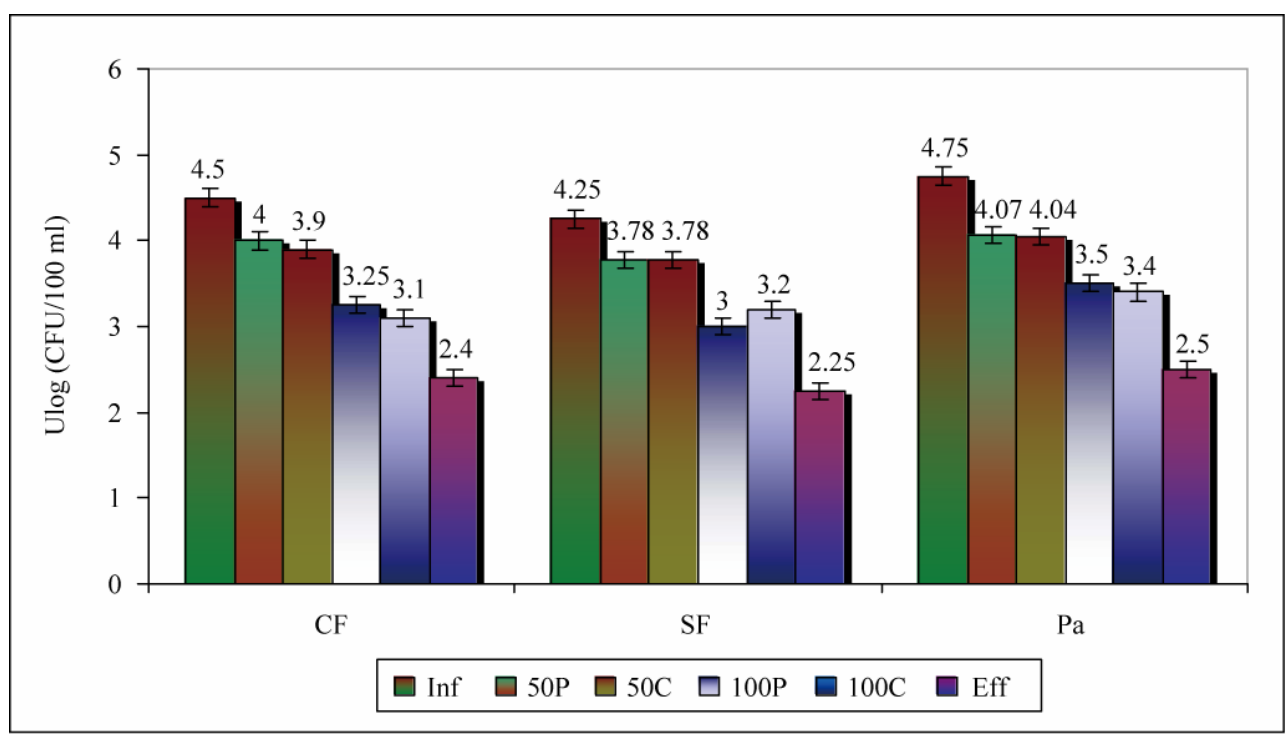

Figure 9. Contents in CF, SF and of Pa in the wastewater before, to $50 \mathrm{~cm}$, to $100 \mathrm{~cm}$, and after treatment by infiltration percolation.

depth of the sand filter. It seems that the logarithm of the concentration of the bacteria decreases in a linear way with the depth equally confirmed by works of Bancole [15]. According to Bali et al. [9], it is the height of the unsaturated sand filter that would influence the elimination of the microorganisms. This fact would be due to the increase in water residence time in sand filter with the amplification of filtration height.

\section{Conclusions}

Oxidation performances of infiltration percolation in Dissa sand filter were very high. Results confirmed that this technique is performed as an advanced treatment system for COD and nitrogen. The experimental study has shown the influence of the filter depth and the vegetaion on the output purification of the process. On the other hand the elimination of the orthophosphate depends on electro-chemical conditions of the middle and not too much the thickness of sand filter. Analyses have shown significant improvements in effluent quality due to the presence of vegetal cover on sand filter surface. Water quality analyses demonstrated that oxidation activity was mainly located in upper sand layers. Disinfection performances were disappointing because of heterogeneous infiltration. Maintaining infiltration surface evenness helps providing uniform infiltration. Infiltration percolation allows oxidizing and disinfecting secondary wastewater effluents. This technique is used as a tertiary treatment with the aim of removing pathogen microorganisms from the effluents of conventional wastewater treatment plants. It is a low technology method that can be used to improve water quality for possible reuse in unrestricted irrigations.

\section{References}

[1] M. Auset, A. Keller, F. Brissaud and V. Lazarova, "Intermittent filtration of Bacteria and Colloids in Porous Media,” Water Resources Research, Vol. 41, Article ID: W09408, 2005, p. 13. doi:10.1029/2004WR003611

[2] A. Bancolé, F. Brissaud and T. Gnagne, "Oxidation Processes and Clogging in Intermittent Unsaturated Infil- tration,” Water Science and Technology, Vol. 48, No. 11, 2003, pp. 139-146.

[3] V. Mottier, F. Brissaud, P. Nieto and Z. Alamy, "Wastewater Treatment by Infiltration Percolation: A Case Study," Water Science and Technology, Vol. 41, No. 1, 2000, pp. 77-84.

[4] G. T. Ausland, K. Stevik, J. F Hanssen, J. C. Kohler and P. D. Jenssen, "Intermittent filtration of Wastewater-Removal of Faecal Coliform Sand Faecal Streptococci," Water Research, Vol. 36, No. 14, 2002, pp. 3507-3516. doi:10.1016/S0043-1354(02)00060-X

[5] M. G. Healy, M. Rodgers and J. Mulqueen, "Treatment of Dairy Wastewater Using Constructed Wetlands and Intermittent Sand Filters,” Bioresource Technology, Vol. 98, No. 12, 2007, pp. 2268-2281. doi:10.1016/j.biortech.2006.07.036

[6] J. A. Faby, F. Brissaud and J. Bontoux, "Wastewater Reuse in France: Water Quality Standards and Wastewater Treatment Technologies," Water Science and Technology, Vol. 40, No. 4-5, 1999, pp. 37-42. doi:10.1016/S0273-1223(99)00483-7

[7] T. Asano, A. Joseph and C. Cotruvob, "Ground Water Recharge with Reclaimed Municipal Wastewater, Health and Regulatory Considerations,” Water Research, Vol. 38, No. 8, 2004, pp. 1941-1951. 
doi:10.1016/j.watres.2004.01.023

[8] H. Makni, R. Boukchina, I. Thabet, S. Iepichi and H. B. Dhia, "L’Utilisation des Sables Naturels dans le Traitement Tertiaire des Eaux Usées Dans le Sud Tunisien,” Proceeding of 13eme Journées Nationales de Chimie, Tunis, Décembre 2004.

[9] M. Bali, M. Gueddari and R. Boukchina, "Treatment of Secondary Wastewater Effluents by Infiltration Percolation,” Desalination, Vol. 258, No. 1-3, 2010, pp. 1-4. doi:10.1016/j.desal.2010.03.041

[10] R. Boukchina, H. Makni, S. Abdedaïem and F. Brissaud, "Amélioration de la Réutilisation Des Eaux Usées en Régions Arides Tunisiennes,” Hydrotop, 2003, pp. 146148.

[11] L. W. Gill, C. Súlleabháin, B. D. Misstear and P. J. Johnston, "The Treatment Performance of Different Sub Soils in Ireland Receiving on Site Wastewater Effluent," Journal of Environmental Quality, Vol. 36, No. 6, 2007, pp. 1843-1855. doi:10.2134/jeq2007.0064
[12] B. Meftah, “Traitement Tertiaire Des Eaux Usées Par Infiltration Percolation,” DEA Faculté des Sciences de Tunis, Tunis, 2004, p. 82.

[13] L. L. Burkitt, C. J. P. Gourley, M. C. Hannah and P. W. D. Sale, "Assessing Alternative Approaches to Predicting Soil Phosphorus Sorption," Soil Use and Management, Vol. 22, No. 4, 2006, pp. 325-333. doi:10.1111/j.1475-2743.2006.00042.x

[14] F. Brissaud, M. Restrepo-Bardon, M. Soulié and C. Joseph, "Infiltration Percolation for Reclaiming Stabilization Pond Effluents,” Water Science and Technology, Vol. 24, No. 9, 1991, pp.185-193.

[15] A. Bancolé, "L’oxydation en Infiltration Percolation," Doct. Thesis, Montpellier II University, Montpellier Cedex, 2001.

[16] O. Iung, "Epuration bacteriologique en infiltration-percolation,” Thèse de Doctorat, Université de Montpellier II, Montpellier Cedex, 1993, p. 305. 